\title{
Pemanfaatan Limbah Agroindustri Kacang Tanah Sebagai Media Pertumbuhan Mikrobia Probiotik Lactobacillus bulgaricus
}

\author{
Utilization of Peanut Agro-Industrial Waste as a Growth Media for Probiotic Bacteria \\ Lactobacillus bulgaricus
}

\section{Esna Dilli Novianto ${ }^{1, *}$, Monica Sonia Indri Pradipta ${ }^{2}$, Suwasdi $^{1}$, Mahdalina Mursilati ${ }^{1}$, Surya Bagus Purnomo ${ }^{2}$}

\author{
${ }^{1}$ Program Studi Agroteknologi, Jurusan Agronomi, Fakultas Pertanian, Universitas Tidar, Jl. Kapten \\ Suparman No. 39, Tuguran, Potrobangsan, Kec. Magelang Utara, Kota Magelang, Jawa Tengah 56116 \\ ${ }^{2}$ Program Studi Peternakan, Jurusan Agronomi, Fakultas Pertanian, Universitas Tidar, Jl. Kapten Suparman \\ No. 39, Tuguran, Potrobangsan, Kec. Magelang Utara, Kota Magelang, Jawa Tengah 56116
}

*Penulis Korespondensi: Esna Dilli Novianto, e-mail: dilli.novianto@untidar.ac.id

Tanggal submisi: 2 April 2020; Tanggal penerimaan: 29 April 2020

\begin{abstract}
The increase of peanut-based agro-industry today, cause a significant increase in the number of waste products in the form of peanut shells. This can cause a problem to the environment due to insoluble carbohydrate fiber molecules in peanuts. However, the cellulose in peanut waste can be used as useful material, such as prebiotic, which plays a role in the growth of probiotic bacteria. Nowadays, inulin is used as a source of prebiotics in food additives or health supplements. However, its limited availability and high prices have an impact on the cost of finished products. This research was aimed to identify and to analyze the crude extracts of peanut shells waste as a prebiotic substitution material. The crude extract of peanut shells waste was used as a growth medium for the probiotic, Lactobacillus bulgaricus. A completely randomized experimental design with levels of treatments, i.e., $0 \%$ (negative control), 20\%, 40\%, 60\%, 80\% of peanut shell extracts, as well as inulin as a positive control was applied in this research to analyze bacterial growth. The parameters observed in this study were the morphology of bacterial colonies, gram staining, and growth curve analysis. The results showed that $60 \%$ concentration of peanut shells extract effectively increased the growth of L. bulgaricus at 6 and 10 hours. Cellulose in rough extracts of peanut shells can be used as a carbon source for bacterial growth.
\end{abstract}

Keywords: peanut shells, prebiotics, probiotics

\begin{abstract}
ABSTRAK
Peningkatan agroindustri berbahan dasar kacang tanah menyebabkan jumlah limbah kulit kacang tanah meningkat secara signifikan, sehingga berdampak pada pencemaran lingkungan. Selulosa pada kulit kacang tanah masih dapat digunakan sebagai bahan prebiotik. Senyawa prebiotik berperan dalam menumbuhkan bakteri probiotik. Pada umumnya, inulin digunakan sebagai sumber prebiotik pada bahan tambahan makanan atau suplemen kesehatan. Ketersediaan yang terbatas dan harga yang mahal berdampak pada harga produk jadi yang lebih mahal. Tujuan penelitian ini untuk mengidentifikasi dan menguji ekstrak kasar limbah agroindustri berupa kulit kacang tanah sebagai bahan substitusi prebiotik. Ekstrak kasar yang didapatkan dari limbah kulit kacang tanah digunakan sebagai media pertumbuhan bakteri probiotik, Lactobacillus bulgaricus. Rancangan acak lengkap satu faktor perlakuan digunakan untuk uji pertumbuhan bakteri $L$. bulgaricus. Variasi konsentrasi ekstrak kulit kacang tanah $0 \%$ (kontrol negatif), 20\%, 40\%, 60\%, $80 \%$ digunakan sebagai perlakuan pada penelitian ini, sedangkan inulin sebagai kontrol positif. Parameter
\end{abstract}


yang diamati pada penelitian inin adalah morfologi koloni bakteri, pengecatan gram dan analisis kurva pertumbuhan. Hasil penelitian menunjukkan bahwa ekstrak kulit kacang tanah konsentrasi $60 \%$ efektif meningkatkan pertumbuhan bakteri $L$. bulgaricus di jam ke-6 dan jam ke-10. Selulosa pada esktrak kasar kulit kacang tanah digunakan sebagai sumber karbon untuk pertumbuhan bakteri.

Kata kunci: kulit kacang tanah, prebiotik, probiotik

\section{PENDAHULUAN}

Aktivitas agroindustri dewasa ini menambah jumlah limbah organik di lingkungan. Salah satunya adalah kulit kacang tanah. Limbah organik kacang tanah menjadi polutan lingkungan jika dibiarkan saja dan tidak diolah dengan benar. Subtansi karbohidrat komplek yang terkandung di dalam limbah kulit kacang dapat mempengaruhi $\mathrm{C} / \mathrm{N}$ ratio tanah sehingga mengganggu perkembangan tanaman yang ada diatasnya (Menezes et al., 2015). Hal tersebut dikarenakan kandungan selulosa pada kacang tanah masih tergolong tinggi, yaitu sekitar 47,19\%, sedangkan kandungan karbohidrat komplek yang lain seperti lignin, hemiselulosa berturut-turut adalah 30,57\% dan 7,19\% (Oktasari, 2018). Menurut Nathalia (2011), kulit kacang tanah juga masih mengandung serabut xylan sekitar 6,3\%. Kandungan serat yang masih tinggi ini dapat digunakan sebagai prebiotik, yaitu makanan bagi bakteri probiotik (mikroflora alami pada tubuh).

Pada saat ini, inulin digunakan sebagai bahan utama prebiotik. Senyawa ini bersinergi dengan senyawa golongan sisi rantai mimosa (Oliveira et al., 2012a). Azhar (2009) dan Tsujikawa et al. (2013) mengemukakan bahwa penambahan inulin dapat meningkatkan jumlah mikroflora alami di dalam tubuh. Sumber inulin saat ini paling banyak ditemukan pada umbi dahlia dan beberapa bahan organik lain sepeti pisang, bawang putih dan tanaman serealia. Namun demikian, ketersediaan inulin yang terbatas dan harga yang mahal berdampak pada harga produk jadi yang lebih mahal. Pemanfaatan limbah organik dengan kandungan serat yang tinggi menjadi alternatif solusi yang tepat untuk menjawab permasalahan tersebut. Salah satunya dengan menggunakan limbah kulit kacang tanah. Suatu bahan dapat dikatakan sebagai prebiotik jika tidak terhidrolisis dan dapat melewati saluran pencernaan atas, hanya dapat digunakan oleh mikrobia tertentu yang termasuk probiotik dan dapat meningkatkan jumlah populasi mikrobia menguntungkan di dalam usus seperti Bifidobacteria, Lactobacillus (Pradipta et al.,
2014) dan Streptococcus (Oliveira et al., 2012a). Pada penelitian ini digunakan bakteri Lactobacillus bulgaricus, salah satu mikrobia starter pada pembuatan minuman probiotik. Berdasarkan penjelasan sebelumnya diketahui bahwa kulit kacang tanah berpotensi sebagai alternatif prebiotik, namun demikian aktivitasnya dalam meningkatkan pertumbuhan bakteri probiotik belum pernah diteliti. Penelitian ini dilakukan untuk mengidentifikasi dan menguji ekstrak kasar kulit kacang tanah sebagai bahan substitusi prebiotik selain inulin melalui uji pertumbuhan bakteri probiotik L. bulgaricus sebagai salah satu mikrobia probiotik yang paling banyak digunakan.

\section{METODE PENELITIAN}

Penelitian dilaksanakan pada bulan April sampai dengan Juli 2019 di Laboratorium Agroteknologi Fakultas Pertanian Universitas Tidar. Metode yang digunakan pada penelitian ini seperti dilakukan oleh Witchencot et al. (2010) dengan dimodifikasi. Secara keseluruhan prosedur penelitian dibagi menjadi tiga tahap utama yaitu preparasi kulit kacang tanah, ekstraksi kulit kacang tanah, dan uji pertumbuhan bakteri probiotik $L$. bulgaricus. Rancangan percobaan menggunakan rancangan acak lengkap satu faktor.

\section{Bahan}

Bahan utama yang digunakan dalam percobaan adalah limbah kulit kacang tanah dan $L$. bulgaricus strain FNCC 0041 koleksi Laboratorium Pangan dan Gizi Universitas Gadjah Mada. Limbah kulit kacang tanah diperoleh dari limbah agroindustri bumbu kacang di daerah Salaman, Kabupaten Magelang.

\section{Preparasi Kulit Kacang Tanah}

Pencucian kulit kacang menggunakan air suling mengalir. Tujuan pencucian adalah menghilangkan kotoran berupa tanah yang menempel pada kulit kacang tanah. Setelah dilakukan pencucian kulit kacang, dilakukan 
pengeringan pertama yaitu dijemur dibawah sinar matahari selama 24 jam ( \pm 3 hari). Kemudian kulit kacang ditimbang dan dilanjutkan dengan proses pengeringan menggunakan oven (Memmert, Germany) dengan suhu $60^{\circ} \mathrm{C}$. Berat kulit kacang diukur menggunakan timbangan analitik secara periodik hingga mendapatkan berat konstan. Kulit kacang tanah yang telah melewati proses pengeringan kemudian dibuat serbuk (crude) dengan menggunakan blender untuk mempermudah proses ekstraksi.

\section{Ekstraksi dan Formulasi}

Ekstraksi menggunakan pelarut air. Ekstraksi dengan air pada suhu kamar dilakukan dengan mencampurkan air dan serbuk kulit kacang tanah dalam perbandingan 5: 1. Pengadukan dilakukan selama 1 jam. Campuran didiamkan selama 24 jam dalam wadah tertutup. Selanjutnya, campuran disaring menggunakan filter kapas kemudian dilanjutkan dengan kertas saring Whatman 42 dengan frekuensi tiga kali penyaringan sampai residu filtrat minimal (jernih). Ekstrak yang diperoleh selanjutnya dicampurkan pada media pertumbuhan basal sesuai level perlakuan dan dilakukan proses sterilisasi menggunakan autoclave (YXQ280 YXQ-280, China) selama 15 menit pada suhu $121^{\circ} \mathrm{C}$ bertekanan 1 atm. Hasil tahapan ekstraksi berupa ekstrak kasar kulit kacang tanah yang dikombinasikan dengan media basal pertumbuhan bakteri, MRSB (Merck, Germany) sesuai dengan kadar crude masing-masing perlakuan dan siap dilakukan inokulasi. Perlakuan kontrol terdiri atas kontrol negatif (KN) menggunakan medium basal dan kontrol positif (KP) dengan inulin ex- Belgia yang didapatkan dari online marketplace. Setiap perlakuan diulang tiga kali. Formulasi media pertumbuhan disajikan dalam Tabel 1.

Tabel 1. Formulasi media pertumbuhan bakteri L. bulgaricus

\begin{tabular}{|c|c|c|}
\hline Kode & Jenis Bakteri & Jenis Perlakuan \\
\hline $\mathrm{LKN}$ & & Media $100 \%$ MRSB \\
\hline L.20 & & Media $20 \%$ ekstrak kasar $+80 \%$ MRSB \\
\hline L.40 & & Media $40 \%$ ekstrak kasar $+60 \%$ MRSB \\
\hline L. 60 & Lactobacıllus bulgaricus & Media $60 \%$ ekstrak kasar $+40 \%$ MRSB \\
\hline L.80 & & Media $80 \%$ ekstrak kasar $+20 \%$ MRSB \\
\hline LKP & & Media $100 \%$ inulin \\
\hline
\end{tabular}

\section{Pengamatan Morfologi Bakteri dan Pengecatan Gram}

Bakteri L. bulgaricus strain FNCC 0041 ditumbuhkan pada media MRSB padat dan di inkubasi pada inkubator (Memmert, Germany) dengan suhu $37^{\circ} \mathrm{C}$ selama $2 \times 24$ jam. Morfologi sel bakteri di amati menggunakan mikroskop cahaya (Hayear, China). Pengecatan gram dilakukan untuk mengetahui bahwa isolat murni yang digunakan sudah sesuai dan bukan merupakan kontaminan. Prosedur pengecatan gram yang digunakan adalah prosedur standar sesuai yang dilakukan oleh Suwasdi et al. (2019). Satu koloni bakteri diambil menggunakan ose. Kemudian isolat di fikasi diatas api bunsen dan dilanjutkan dengan pengecatan berturut-turut Gram A (kristaln violet), Gram B (Iod), Gram C (Alkohol 70\%) dan Gram D (Safranin). Kenampakan warna bakteri di amati menggunakan mikroskop cahaya pada perbesaran 400 kali.

\section{Uji Pertumbuhan Bakteri Probiotik Asam Laktat}

Inokulum L. bulgaricus strain FNCC 0041 disiapkan dengan inokulasi pada formulasi media pertumbuhan (sesuai perlakuan) diinkubasi pada incubator (Memmert, Germany) dengan suhu $37^{\circ} \mathrm{C}$ dan dilakukan perhitungan koloni menggunakan haemocytometer (Marienfeld, Germany) selama 12 jam masa inkubasi dengan interval perhitungan 2 jam. Data hasil perhitungan bakteri pada haemocytometer kemudian dihitung untuk mendapatkan CFU/mL (Colony Forming Units) dan dikonversi dalam bentuk kurva pertumbuhan untuk memperoleh pola pertumbuhan dengan fase logaritmik optimal. 


\section{HASIL DAN PEMBAHASAN}

\section{Morfologi Bakteri dan Pengecatan Gram}

Teknik pewarnaan membagi bakteri berdasarkan struktur senyawa penyusun dinding sel. Dinding sel bakteri Gram positif tersusun atas senyawa karbohidrat kompleks peptidoglikan yang berbentuk seperti jala. Peptigoglikan menyumbang $50-90 \%$ berat selubung sel. Bakteri Gram negatif memiliki dinding sel dengan lapisan peptidoglikan yang lebih tipis sekitar 10\% berat selubung sel (Putri et al., 2018).

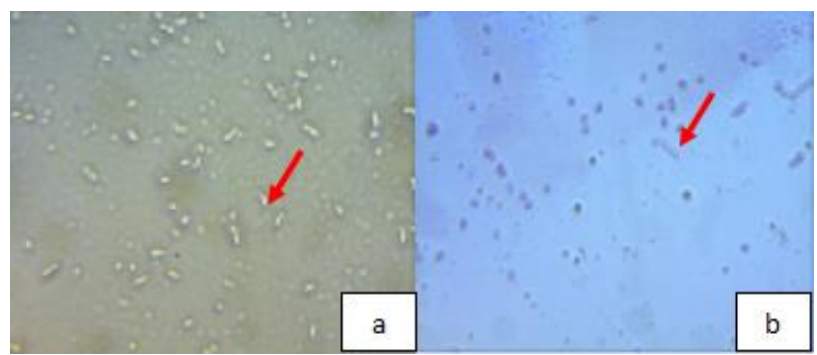

Gambar 1. Pewarnaan probiotik dengan perbesaran 400 kali: a) Lactobacillus bulgaricus biakan; b) Lactobacillus bulgaricus murni

Hasil pewarnaan isolat yang ditumbuhkan dalam media kandidat prebiotik ekstrak kasar limbah kulit kacang tanah menunjukkan jenis bakteri gram positif dengan warna keunguan. Hal tersebut dapat dilihat pada gambar 1 yang ditunjuk oleh anak panah. Struktur morfologi Lactobacillus bulgaricus sesuai dengan data strain yang diperoleh dari Laboratorium Pusat Studi Pangan dan Gizi Universitas Gadjah Mada dengan bentuk sel memanjang (batang) dan bentuk koloni berkelompok (Oliveira et al., 2012b; Takagi et al., 2014). Hasil dari pengamatan morfologi (koloni ataupun sel) dan pengecatan Gram menunjukkan bahwa bakteri yang ditumbuhkan adalah benar bakteri probiotik L. bulgaricus dan bukan bakteri kontaminan sehingga penelitian dapat dilanjutkan ke tahap berikutnya. Populasi koloni yang teramati antara media MRSB lebih tinggi dibandingkan dengan media ekstrak kulit kacang tanah. Hal ini disebabkan media MRSB merupakan media basal dengan nutrisi cukup yang dibutuhkan bagi pertumbuhan bakteri probiotik asam laktat. Kadar selulosa dalam ekstrak kulit kacang tanah dapat digunakan sebagai media pertumbuhan probiotik asam laktat walaupun populasi koloni yang teramati belum setara dengan media basal MRSB.
Faktor ketersediaan nutrisi yang menjadi faktor pembatas bagi pertumbuhan probiotik asam laktat yang dikulturkan. Media basal MRSB memiliki kandungan glukosa sebanyak $20 \mathrm{~g} / \mathrm{L}$. Menurut Suwasdi et al. (2019) bakteri asam laktat lebih mudah menggunakan karbohidrat sederhana daripada karbohidrat kompleks seperti pada ekstrak kulit kacang. Hal inilah yang menyebabkan koloni $L$. bulgaricus lebih banyak tumbuh di media MRSB daripada media dengan tambahan ekstrak kulit kacang tanah.

\section{Analisis Kurva Pertumbuhan Bakteri Asam Laktat}

Rohan et al. (2016) menyebutkan kurva pertumbuhan bakteri dibagi kedalam empat tahapan yaitu fase initial (lag phase), fase kuadratik (log phase), fase stasioner (stasioner phase), dan fase deklinasi (death phase).

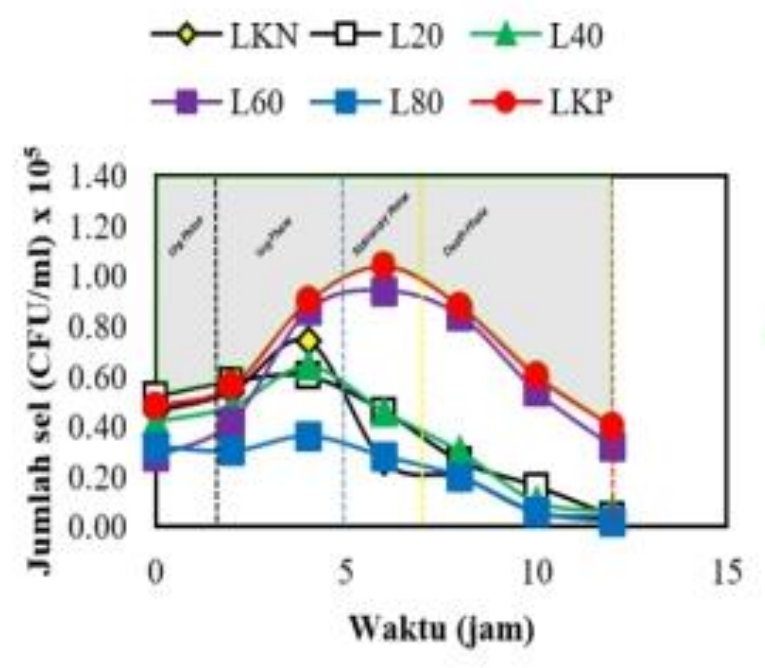

Gambar 2. Kurva pertumbuhan bakteri Lactobacillus bulgaricus

Hasil penelitian yang dilakukan menunjukkan fase initial (lag phase) terjadi antara jam ke-0 sampai ke-4 setelah inokulasi untuk semua perlakuan. Lag phase merupakan fase mikroba menyesuaikan diri dengan kondisi lingkungan di sekitarnya dalam hal ini media pertumbuhan yang baru (Cobas et al., 2011). Faktor yang mempengaruhi fase initial ini diantaranya adalah jumlah sel pertama yang di inokulasi, kondisi fisiologis dan morfologis mikrobia itu sendiri dan jenis media pertumbuhan yang digunakan. Takagi et al. (2014) melaporkan 
fase initial (lag phase) L. bulgaricus terjadi pada jam ke- sampai dengan jam ke-4 setelah dilakukan inokulasi pada media pertumbuhan baru. Fase logaritmik (log phase) terjadi karena bakteri melakukan pembelahan biner pada laju konstan, dimana jumlah bakteri menjadi dua kali lipat pada periode waktu tertentu, keadaan pertumbuhan seimbang, serta memiliki laju metabolism tetap. Fase tersebut merupakan fase yang tepat untuk mengambil isolat bakteri sebagai bahan starter (Sharah et al., 2015; Suwasdi et al., 2019).

Fase logaritmik L. bulgaricus yang teramati pada percobaan berkisar antara 2-5 jam. Hal tersebut terlihat pada grafik perlakuan kontrol positif dan perlakuan penambahan ekstrak kulit kacang 60\% (L.60). Minj dan Vij (2012) memaparkan bahwa bakteri probiotik $L$. bulgaricus LB144 memiliki fase pertumbuhan logaritmik optimal pada jam ke-3 sampai jam ke-6 pada inokulasi media MRS dengan penambahan 3\% inulin. Hasil percobaan yang dilakukan diperoleh fase logaritmik optimal terdapat pada perlakuan media inulin dengan titik optimum $L$. bulgaricus adalah $1,04 \times 10^{5}$. L. bulgaricus media inulin mecapai titik optimum logaritmik antara jam ke-6 sampai jam ke-8 (Gambar 2, grafik LKP dan L.60) setelah inokulasi. Pada L. bulgaricus media pertumbuhan ekstrak kasar kulit kacang tanah pada perlakuan konsentrasi $60 \%$ (L.60) dengan jumlah bakteri (CFUs/mL) pada titik optimum 9,4 × $10^{5}$ antara jam ke-4 sampai ke-6. Ekstrak kasar kulit kacang tanah digunakan oleh bakteri asam laktat sebagai bahan karbon dalam metabolisme sel. Senyawa karbon diperoleh dari kandungan selulosa dalam kulit kacang tanah yang dihidrolisis bersamaan dengan media basal. Pada konsentrasi diatas $60 \%$, bahan karbon yang terdapat pada media memiliki konsentrasi terlalu tinggi sehingga akan menghambat proses pembelahan sel.

Hasil percobaan menunjukkan fase stasioner L. bulgaricus berkisar antara jam ke-6 sampai jam ke-7 (Gambar 2, grafik LKP dan L.60). Fase stasioner bakteri terjadi karena jumlah bakteri yang hidup sama hampir sama dengan jumlah bakteri yang mati. Hal ini disebabkan berkurangnya nutrien dan terbentuknya senyawa hasil metabolisme yang cenderung bersifat racun bagi bakteri. Fase ini terjadi penumpukan asam laktat, sebagai hasil metabolisme bakteri $L$. bulgaricus. Selain itu, penyusutan kandungan nutrien pada media pertumbuhan, mengakibatkan terjadinya kompetisi perebutan nutrisi sehingga hanya sel yang mampu bertahan yang akan tetap tumbuh, sedangkan sel yang tidak mampu berkompetisi akan mati (Reiny, 2012). Fase stasioner bakteri asam laktat cenderung singkat karena hasil metabolit berupa asam laktat akan menjadi zat penghambat pada pembelahan sel bakteri.

Fase kematian $L$. bulgaricus mulai terjadi setelah jam ke-7 setelah inkubasi (Gambar 2, grafik LKP dan L.60). Fase kematian (death phase) sel yang mati menjadi lebih banyak dari pada terbentuknya sel-sel yang baru. Rohan et al. (2016) dan Pradipta et al. (2017) memaparkan mikroba pada fase kematian disebabkan oleh beberapa faktor antara lain jumlah nutrisi yang telah habis, umur sel mikroba, dan adanya hasil metabolit sekunder dari proses metabolisme sel yang antara lain asam laktat, alkohol dan sebagainya.

Hasil analisis pertumbuhan probiotik bakteri asam laktat $L$. bulgaricus disajikan pada Tabel 2 . Berdasarkan hasil analisis yang telah dilakukan konsentrasi ekstrak kulit kacang tanah pada berbagai level tidak menunjukkan perbedaan signifikan $(P>0,05)$ pada pertumbuhan $L$. bulgaricus pada 0,2 , dan 4 jam. Hal ini sesuai dengan dugaan awal bahwa pada jam-jam tersebut, bakteri $L$. bulgaricus sedang berada pada fase initial (lag phase). Fase ini umum terjadi pada semua bakteri ketika dipindahkan ke dalam media pertumbuhan yang baru.

Pertumbuhan L. bulgaricus pada fase lag dan log tidak dipengaruhi perbedaan konsentrasi ekstrak kulit kacang tanah yang diberikan. Namun pada waktu 6 jam hingga 10 jam terlihat perbedaan yang signifikan $(P<0,05)$ di antara perlakuan yang diberikan pada fase stasioner L. bulgaricus. Penambahan ekstrak kasar kulit kacang tanah $60 \%$ (L.60) pada fase tersebut, menunjukkan hasil yang tidak berbeda nyata dibandingkan perlakuan inulin (kontrol positif). Artinya pada konsentrasi ekstrak kasar kulit kacang tanah 60\% (L.60), media ini mampu menggantikan inulin untuk mempertahankan pertumbuhan bakteri L. bulgaricus. 
Tabel 2. Efek penambahan ekstrak kasar kulit kacang tanah terhadap pertumbuhan probiotik bakteri asam laktat

Waktu Pertumbuhan Lactobacillus bulgaricus

Perlakuan $\left(\times 10^{5} \mathrm{CFU}\right)(\mathrm{jam})$

\begin{tabular}{lccccccc} 
& $\mathbf{0}$ & $\mathbf{2}$ & $\mathbf{4}$ & $\mathbf{6}^{*}$ & $\mathbf{8}^{\mathbf{*}}$ & $\mathbf{1 0}^{*}$ & $\mathbf{1 2}^{*}$ \\
\hline LKN & 0,46 & 0,54 & 0,74 & $0,26^{\mathrm{a}}$ & $0,20^{\mathrm{a}}$ & $0,06^{\mathrm{a}}$ & $0,04^{\mathrm{a}}$ \\
L.20 & 0,52 & 0,52 & 0,60 & $0,46^{\mathrm{b}}$ & $0,26^{\mathrm{a}}$ & $0,16^{\mathrm{a}}$ & $0,05^{\mathrm{a}}$ \\
L.40 & 0,42 & 0,43 & 0,64 & $0,46^{\mathrm{b}}$ & $0,30^{\mathrm{a}}$ & $0,20^{\mathrm{a}}$ & $0,30^{\mathrm{b}}$ \\
L.60 & 0,28 & 0,42 & 0,86 & $0,94^{\mathrm{c}}$ & $0,84^{\mathrm{b}}$ & $0,54^{\mathrm{b}}$ & $0,32^{\mathrm{b}}$ \\
L.80 & 0,32 & 0,30 & 0,36 & $0,28^{\mathrm{a}}$ & $0,20^{\mathrm{a}}$ & $0,06^{\mathrm{a}}$ & $0,02^{\mathrm{a}}$ \\
LKP & 0,48 & 0,56 & 0,90 & $1,04^{\mathrm{c}}$ & $0,88^{\mathrm{b}}$ & $0,60^{\mathrm{b}}$ & $0,54^{\mathrm{c}}$
\end{tabular}

Keterangan: *Karakter huruf/superskrip yang berbeda pada kolom yang sama menunjukkan perbedaan yang nyata $(P<0,05)$

Menurut Cobas et al. (2011) pada media pertumbuhan yang baru, bakteri akan melakukan adaptasi untuk dapat bertahan hidup. Keberhasilan adaptasi ini ditunjukkan dengan terbentuknya kurva pertumbuhan logaritmik yang diikuti dengan fase stasioner pada waktu tertentu. Inulin digunakan sebagai kontrol positif pada penelitian ini. Berdasarkan penjelasan sebelumnya, kurva pertumbuhan yang dihasilkan pada perlakuan penambahan ekstrak kulit kacang tanah 60\% menunjukkan gambar yang setara dibawah kontrol positif. Hal tersebut diperkuat dengan hasil analisa statistik pada tabel 1 yang menunjukkan tidak ada perbedaan nyata antara perlakukan L.60 dengan kontrol positif LKP. Hal tersebut tidak dijumpai pada perlakuan penambahan ekstrak kulit kacang tanah konsentrasi lainnya. Dengan demikian dapat dikatakan bahwa konsentrasi ekstrak kulit kacang tanah sebanyak $60 \%$ merupakan konsentrasi yang tepat sebagai alternatif pengganti inulin.

Uji statistik juga dilakukan pada fase kematian bakteri. Perlakuan L.60 menunjukkan perbedaan nyata dengan kontrol positif $(P>0,05)$. Hal ini menunjukkan bahwa setelah jam ke 10, pada perlakuan L.60 sudah memasuki fase kematian seperti pada perlakuan konsentrasi ekstrak kulit kacang lainnya. Hasil uji ini menegaskan bahwa konsentrasi ekstrak 60\% hanya dapat digunakan hingga jam ke 10 setelah bakteri pertama di inokulasi. Setelah jam tersebut, penambahan ekstrak kulit kacang tanah tidak memberikan efek yang signifikan.

\section{KESIMPULAN}

Penggunaan ekstrak kasar limbah kulit kacang tanah konsentrasi $60 \%$ pada L. bulgaricus waktu 6 hingga 10 jam menunjukkan perbedaan tidak signifikan $(P>0,05)$ dibandingkan inulin (kontrol positif). Artinya konsentrasi ekstrak kasar kulit kacang tanah 60\% L. bulgaricus mampu menggantikan inulin untuk mempertahankan pertumbuhan bakteri tersebut.

\section{DAFTAR PUSTAKA}

Azhar, M. 2009. Inulin sebagai prebiotik. Jurnal Sainsteks 8: 1-8.

Cobas, A.C. N. Corzo, A. Olano, C. Peláez, T. Requena, and M. Ávila. 2011. Galactooligosaccharides derived from lactose and lactulose: Influence of structure on Lactobacillus, Streptococcus, and Bifidobacterium growth. International Journal of Food Microbiology 149: 81-87. DOI: 10.1016/j.ijfoodmicro.2011.05.026

Menezes, A.B., M.T.P. Miller, P. Poonpatana, M. Farrell, A. Bissett, L.M. Macdonald, P. Toscas, A.E. Richardson, and P.H. Thrall. 2015. C/N ratio drives soil actinobacterial cellobiohydrolase gene diversity. Environmental Microbiology 81: 3016-3028. DOI: 10.1128/AEM.00067-15

Minj, J. and S. Vij. 2012. Effect of prebiotic inulin on the fermentation and growth kinetics pattern of probiotic yoghurt bacteria. International Journal of Current Microbiology and Applied Sciences 6: 17551768. DOI:10.20546/ijcmas.2017.612.199

Nathalia, D.N. 2011. Produksi Xilooligosakarida dari Tongkol Jagung Sebagai Kandidat Prebiotik Dengan Pemanasan Suhu Tinggi dan Hidrolisis Enzimatik. Tesis. Bogor: Institut Pertanian Bogor. 
Oktasari, A. 2018. Kulit kacang tanah (Arachis hypogaea L.) sebagai adsorben ion $\mathrm{Pb}(\mathrm{II})$. Jurnal ALKIMIA 2: 17-27. DOI: 10.19109/alkimia.v2i1.2258

Oliveira, R.P.S., P. Perego, M.N. de Oliveira, and A. Converti. 2012a. Effect of inulin on the growth and metabolism of a probiotic strain of Lactobacillus rhamnosus in co-culture with Streptococcus thermophilus. LWTFood Science and Technology 47: 358-363. DOI: 10.1016/j.lwt.2012.01.031

Oliveira, R.P.S., P. Perego, M.N. De Oliveira, and A. Converti. 2012b. Growth, organic acids profile and sugar metabolism of Bifidiobacteria lactics in co-culture with Streptococcus thermophilus: the inulin effect. Food Research International 48: 2127. DOI: 10.1016/j.foodres.2012.02.012

Pradipta, M.S.I., S. Harimurti, and Widodo. 2017. Microencapsulation of indigenous poultry lactic acid bacteria probiotic on the competitive exclusion against Salmonella enteritidis and Escherichia coli in vitro. Bulletin Peternakan 41: 134-141. DOI: 10.21059/buletinpeternak.v41i2.17017

Putri, Y.W., A.E. Putra, dan B.I. Utama. 2018. Identifikasi dan karakteristik bakteri asam laktat yang di isolasi dari vagina wanita usia subur. Jurnal Kesehatan Andalas 7: 20-25. DOI: $10.25077 / \mathrm{jka} . v 7 \mathrm{i0.864}$

Reiny, S.S. 2012. Potensi filtrat Lactobacillus acidophilus ATCC $4796 \quad$ sebagai biopreservatif pada rebusan daging ikan tongkol. Indonesian Journal of Applied

$$
\text { Science 2: 604-613. DOI: }
$$$$
\text { 10.24198/ijas.v2i2.2734 }
$$

Rohan, H.S., N.L.P.E. Sudiwati, K. Rokhmad, dan I.R. Rohana. 2016. Mikrobiologi Dasar. Yogyakarta: CV. Budi Utama.

Sharah, A., R. Kumalasari, dan Desmelati. 2015. Pembuatan kurva pertumbuhan bakteri asam laktat yang di isolasi dari ikan peda kembung (Rastrelliger sp.). Jurnal Online Mahasiswa Universitas Riau 2: 1-8.

Suwasdi, M., Mursilati, S. Bagus, M.S.I. Pradipta, and E.D. Novianto. 2019. Utilization of peanut shell waste (Arachis hypogaea) as a growth media for probiotic bacteria Streptococcus thermophilus. Journal of Livestock Science and Production 3: 186192. DOI: 10.31002/jalspro.v3i2.2035

Takagi, R., Y. Tsujikawa, R. Nomoto, and R. Osawa. 2014. Comparison of the growth of Lactobacillus delbrueckii, L. paracasei and L. plantarum on inulin in co-culture systems. Journal Bioscience of Microbiota, Food and Health 33: 139-146. DOI: 10.12938/bmfh.33.139

Tsujikawa, Y., R. Nomoto, and R. Osawa. 2013. Difference in degradation patterns on inulintype fructans among strains of Lactobacillus delbrueckii and Lactobacillus paracasei. Bioscience of Microbiota, Food and Health 32: 157-165. DOI: 10.12938/bmfh.32.157

Wichienchot, A., M. Jatupornpipat, and R.A. Rastall. 2010. Oligosaccharide of pitaya (Dragon Fruit) flesh and their prebiotic properties. Food Chemistry 120: 850-857. DOI: 10.1016/j.foodchem.2009.11.026 